\title{
The impact of propranolol on apoptosis in cutaneous squamous cell carcinomas
}

\author{
Celik E${ }^{1}$, Kaplan $\mathrm{HM}^{2}$, Singirik $\mathrm{E}^{2}$ \\ Department of Dermatology, Faculty of Medicine, Hatay Mustafa Kemal University, Hatay, Turkey. \\ ebruecelik@yahoo.com
}

\section{ABSTRACT}

OBJECTIVES: Cutaneous squamous cell carcinoma (cSCC) is a common cancer in Caucasian populations. Treatments registered for high-risk CSCC are still undetermined. Experimental data have demonstrated possibly useful effects of a combined application of beta-blockers in cancer therapy. The goal of this study was to examine the efficacy of propranolol in the treatment of cSCC and its impact on apoptosis. Thus, we aimed to investigate the apoptotic pathway protein levels and activity in beta-blocker-treated cSCC cells. MATERIALS AND METHODS: The study was performed on human cSCC cancer cell line culture. One of the cSCC cell lines was treated with propranolol, whereas no treatment was given to the other group. Then, the levels of apoptotic pathway proteins were determined by ELISA test in both groups.

RESULTS: The propranolol treatment group exhibited a remarkable difference as compared with the other group. It was found that propranolol treatment enhanced the activity of caspase- 3 while the expression of bax, wee1, gadd153, grp78 and AIF decreased bcl-2 which is antiapoptotic protein in cSCC cell lines. CONCLUSION: Our results suggest that propranolol treatment has anti-cancer properties with an effect on various apoptotic pathways in CSCC. These data are important because propronalol may be involved in future cSCC treatment (Tab. 1, Fig. 3, Ref. 22). Text in PDF www.elis.sk

KEY WORDS: beta-blocker, propranolol, cutaneous squamous cell carcinoma, apoptotic pathway.

\section{Introduction}

Cutaneous squamous cell carcinoma is a cancer induced by malignant proliferation of keratinocytes of the epidermis that have invaded into the dermis or beyond (1). Cutaneous squamous cell carcinoma (cSCC) is estimated to account for $20-30 \%$ of cutaneous malignancies, being one of the prevalent cancers in Caucasians. More than 1 million cases of squamous cell carcinoma are diagnosed each year in the U.S. Its incidence has increased up by 200 percent in the past three decades in the U.S., and more than 15,000 Americans die each year from the disease (2). While the risk of metastasis is low in most patients, aggressive SCC is related with very high mortality and morbidity. Early treatment is crucial to cure cSCC. Although cSCC can be treated with surgical removal, radiation and chemotherapy alone or in combination, the prognosis of patients with metastatic SCC is lacking. Even though the majority of cSCCs can be treated surgically, the addi-

${ }^{1}$ Department of Dermatology, Faculty of Medicine, Hatay Mustafa Kemal University, Hatay, Turkey, and ${ }^{2}$ Department of Pharmacology, Faculty of Medicine, Cukurova University, Adana, Turkey

Address for correspondence: E. Celik, MD, Hatay Mustafa Kemal University, Tayfur Sokmen Campus, Faculty of Medicine, Department of Dermatology, Serinyol Antakya, Hatay, Turkey

Phone: +90.326.2291000, Fax: +90.326.2455305

Acknowledgement: This study was supported by the Hatay Mustafa Kemal University Scientific Projects Coordination Unit (Project No: 17M001), Hatay, Turkey. tional workup and treatments recorded for high-risk cSCC are still unclear. Despite the fact that high-stage $\mathrm{cSCC}$ can be sensitive to several chemotherapeutic agents, there is no standard regimen. Today, chemotherapy with cisplatin alone or along with 5-FU is being carried out with positive responses. However, according to the National Comprehensive Cancer Network Guidelines, the evidence regarding systemic therapies for distant metastatic cSCC is limited (1).

Propranolol is a non-selective $\beta$-blocker widely used for the treatment of hypertension. It is a safe and effective agent for firstline treatment of infantile haemangiomas, one of the benign vascular tumours. Propranolol has anti-proliferative, anti-migratory, anti-angiogenic and cytotoxic characteristics in a wide variety of cancers. Experimental data have demonstrated possibly beneficial effects of a combined administration of beta-adrenergic receptor antagonists ( $\beta$-blockers) in cancer therapy. Despite their major side effects, including hypoglycaemia, hypotension and bradycardia, they are well tolerated $(3,4)$.

It has been reported that catecholamines and beta-adrenergic signalling have a significant impact on the growth of secondary tumours (5-7). Accordingly, propranolol is interesting as it reveals the effect of skin cancer cells on the apoptotic pathway. With this aim, human cSCC cell lines were cultured and the effects of propranolol on apoptosis mediators in these cells were examined.

The goal of this study was to evaluate the efficacy of propranolol in the treatment of $\mathrm{cSCC}$ and its impact on apoptosis. Hence, we aimed to investigate the levels of apoptotic pathway proteins 


\section{1-804}

(caspase-3, bax, bcl-2, wee 1, gadd153, grp78, and AIF protein) and the activity in beta-blocker-treated cSCC cells.

\section{Materials and methods}

\section{Cell culture}

Human cSCC cell lines A431 were obtained. Squamous cancer cells were cultured in Dulbecco's modified Eagle's medium (DMEM) containing $4 \mathrm{mM} \mathrm{L}$-glutamine, $1 \mathrm{mM}$ sodium pyruvate, $4,500 \mathrm{mg} / \mathrm{L}$ glucose, and $1,500 \mathrm{mg} / \mathrm{L}$ sodium bicarbonate. The cells were incubated at $37{ }^{\circ} \mathrm{C}$ in a humidified incubator supplying $5 \% \mathrm{CO}_{2}$.

\section{Cell viability assay (MTT assay)}

$5 \mathrm{mg} / \mathrm{mL}$ dose of MTT (3-(4,5-dimethylthiazol-2-yl)-2,5 diphenyl tetrazolium bromide; sigma) was prepared by dissolving MTT in filtered phosphate-buffered saline (PBS). Cells were plated at a density of 104 cells/cm2 in 96-well plates in the final volume of $180 \mu \mathrm{L}$ of medium and incubated overnight. The cells were then treated once with a dose of $100 \mu \mathrm{mol} / \mathrm{L}$ of propranolol and observed after $48 \mathrm{~h}$. Following the treatment with propranolol, MTT was added to each well at a $1 / 10$ volume for $3 \mathrm{~h}$ at $37^{\circ} \mathrm{C}$. The supernatants were carefully aspirated, a volume of $100 \mu \mathrm{L}$ of dimethyl sulfoxide was added to each well, and the plates were agitated to dissolve the crystal product. Absorbance of plates were measured at $570 \mathrm{~nm}$.

\section{Quantitative analysis: cell homogenization}

Cells $\left(5 \times 104\right.$ cells $\left./ \mathrm{cm}^{2}\right)$ were exposed to $100 \mu \mathrm{mol} / \mathrm{L}$ propranolol for $48 \mathrm{~h}$. They were then washed in PBS and lysed in RIPA buffer (150 mmol/L NaCl 0.5\%, TritonX-100, $20 \mathrm{mmol} / \mathrm{L}$ EGTA, $1 \mathrm{mmol} / \mathrm{L}$ dithiothreitol, $25 \mathrm{mmol} / \mathrm{L} \mathrm{NaF}, 50 \mathrm{mmol} / \mathrm{L}$ Tris$\mathrm{HCl}$ [pH 7.4], $1 \mathrm{mmol} / \mathrm{L} \mathrm{Na} 3 \mathrm{VO} 4)$ for $15 \mathrm{~min}$ on ice and then centrifuged at 15,000 rpm for $20 \mathrm{~min}$; supernatants were taken and pellets discarded.

\section{Protein quantification}

Bradford method was employed to quantify the total protein in homogenized tissues. By using bovine serum albumin $(1 \mu \mathrm{g} / \mathrm{ml}), 1$, $2,3,5,7,8$, and $10 \mu \mathrm{g} / \mathrm{mL}$ standards were prepared. A volume of $10 \mu \mathrm{L}$ was taken from every sample and distilled water was added to increase the volume up to $100 \mu \mathrm{L}$. A volume of $1 \mathrm{~mL}$ of Bradford solution was added to standards and samples, vortexed, and absorbances at 595 nanometres were measured manually. Protein quantification $(\mu \mathrm{g} / \mu \mathrm{L})$ was done according to the standard curve drawn in Prism software.

\section{ELISA (enzyme-linked immunosorbent assay)}

ELISA test was used to examine the activity of caspase-3 and expression of bax, bcl-2, wee 1, gadd153, grp78, and AIF protein.

\section{Statistical analyses}

For comparing the parameters of the propranolol-treated group from those of the control group, unpaired Student's t test was used. Data are presented as mean \pm SEM. Statistical analysis of differen-

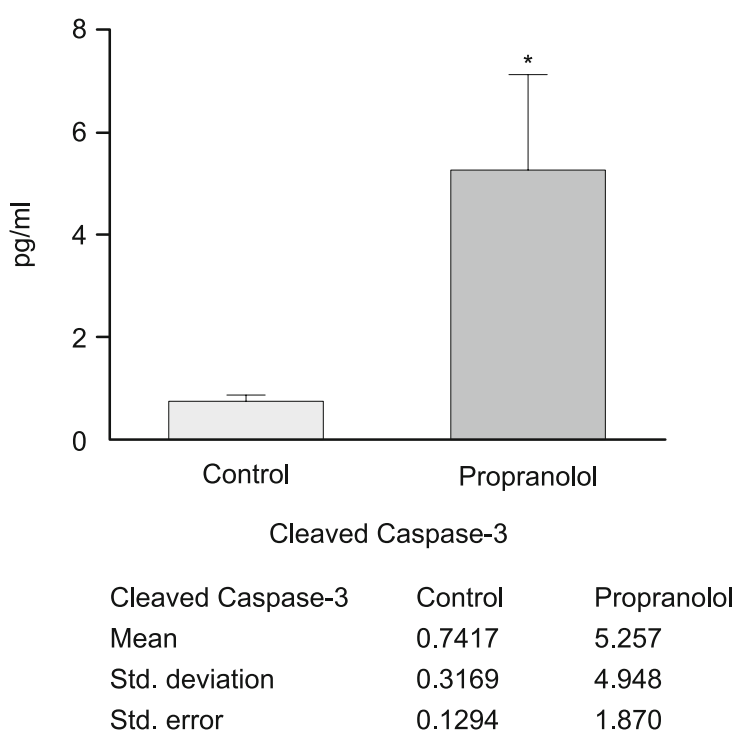

Fig. 1. Propranolol treatment increased the activity of apoptotic protein (caspase-3) in cSCC cells. Statistical analysis: Student t test. (*: for control $p<0.05$ ).

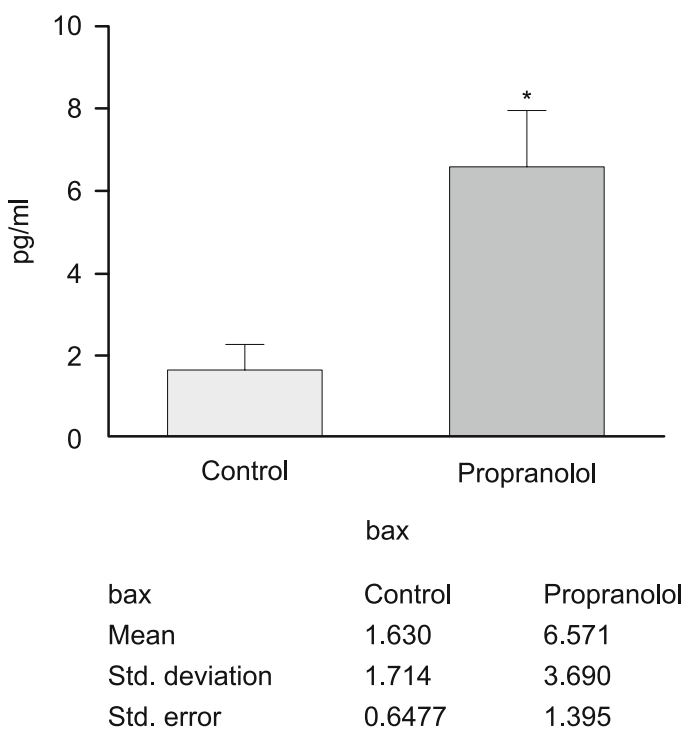

Fig. 2. Propranolol treatment increased the activity of apoptotic protein (bax) in cSCC cells. Statistical analysis: Student $t$ test. (*: for control $\mathrm{p}<0.05$ ).

ces was performed while $\mathrm{p}<0.05$ was taken as an indicator of significance.

\section{Results}

Propranolol treatment enhanced the expression of apoptotic proteins (caspase-3, bax, wee 1, gadd153, grp78 and AIF) (Figs 1 and 2, Tab. 1) and decreased the antiapoptotic protein level (bcl-2; Fig. 3) in cSCC cells. Propranolol treatment also reduced the viability of human cSCC cells. The data presented below are mean 
Tab. 1. Propranolol treatment increased the activity of apoptotic proteins (wee 1, AIF, gadd153, grp78) in cSCC cells.

\begin{tabular}{lcc}
\hline & Control & Propranolol \\
\hline wee 1 & $0.28 \pm 0.015 \mathrm{pg} / \mathrm{mL}$ & $0.98 \pm 0.07 \mathrm{pg} / \mathrm{mL}^{*}$ \\
AIF & $0.75 \pm 0.018 \mathrm{pg} / \mathrm{mL}$ & $2.5 \pm 0.18 \mathrm{pg} / \mathrm{mL}^{*}$ \\
gadd153 & $0.25 \pm 0.02 \mathrm{pg} / \mathrm{mL}$ & $2,1 \pm 0.21 \mathrm{pg} / \mathrm{mL}^{*}$ \\
grp78 & $0.78 \pm 0.025 \mathrm{pg} / \mathrm{mL}$ & $3.1 \pm 0.25 \mathrm{pg} / \mathrm{mL}^{*}$ \\
\hline \multicolumn{2}{l}{ Results are presented as mean \pm SE. Statistical analysis: Student's t test. (*: for } \\
control p $<0.05$ )
\end{tabular}

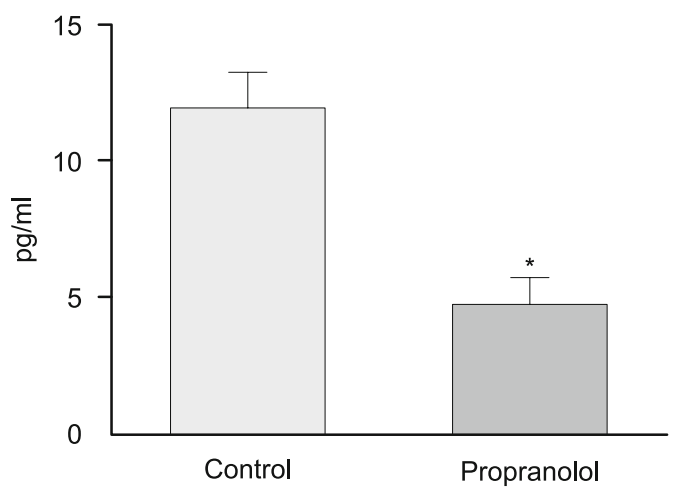

bcl-2

$\begin{array}{lll}\text { bcl-2 } & \text { Control } & \text { Propranolol } \\ \text { Mean } & 12.00 & 4.788 \\ \text { Std. deviation } & 3.674 & 2.783 \\ \text { Std. error } & 1.225 & 0.9841\end{array}$

Fig. 3. Propranolol treatment decreased antiapoptotic protein (bcl-2) in cSCC cells. Statistical analysis: Student t test. $(*$ : for control $p<0.05)$.

results of the control and propranolol-treated groups, respectively: wee $1(0.28$ and $0.98 \mathrm{pg} / \mathrm{mL}), \operatorname{AIF}(0.75$ and $2.5 \mathrm{pg} / \mathrm{mL})$, gadd 153 (0.25 and $2.1 \mathrm{pg} / \mathrm{mL})$, grp78 (0.78 and $3.1 \mathrm{pg} / \mathrm{mL})$, cleaved caspase-3 (0.74 and $5.25 \mathrm{pg} / \mathrm{mL})$, bax (1.63 and $6.57 \mathrm{pg} / \mathrm{mL})$, bcl-2 $(12.0$ and $4.78 \mathrm{pg} / \mathrm{mL})$. The comparison of these two groups revealed that all assessed values were significantly different $(p<0.05)$.

\section{Discussion}

Cutaneous squamous cell carcinoma (cSCC) is a malign transformation of cutaneous epithelium. The primary treatment of cSCCs is surgical excision. However, even if the lesion is surgically removed, there is still the risk of recurrence, metastasis and death. It has been reported that there is more mutation in cSCC malignities than in melanoma or lung cancer. Tumour protein 53 (TP53) is the tumour-inhibiting gene exposed to the most prevalent mutation in patients. Dysplasia developed in keratinocytes due to mutations and cell modifications may lead to cSCC. TP53 mutations enables the resistance of tumour cells to apoptosis and their clonal expansion despite adjacent normal keratinocytes. Moreover, there are such mutations as kinase inhibitors $2 \mathrm{~A}$ mutations which play a role in the cycle of control proteins, ras mutations which have an impact on cell signal transference, mutations of Notch homolog 1 which is another inhibiting gene, and there are many other mutations. Recently, the efforts to resolve the molecular basis of the disease have paved the way for targeted drugs and immunologic treatments. Yet the common opinion is that the presence of multiple mutations will make it impossible to apply a single-agent targeted therapy. There is no such special therapy determined for cSCC (8). Adjuvant chemotherapy combinations 5-fluorouracil (5-FU)/cisplatin, 5-FU/carboplatin or paclitaxel/carboplatin) or adjuvant radiotherapy are therapies applied to date to high-risk patients after the surgical removal of cSCC lesion. Furthermore, topical agents employed for the treatment and inhibition of cSCC are 5-fluorouracil, topical retinoids, imiquimod, ingenol mebutate, diclofenac, and photodynamic therapy. Other oral and systemic agents applied for this purpose include oral retinoids, nicotinamide, capecitabine, sirolimus, aspirin and NSAIDs (9).

Propranolol, a beta-blocker, is a therapeutic agent used in the treatment of various types of cancer due to its anti-proliferative, anti-migratory, anti-angiogenic and cytotoxic features $(3,4)$.

$\beta$-adrenergic effects on stromal cells in the tumour microenvironment generally synergize with the direct effects on tumour cells in promoting cancer survival, growth, and metastatic dissemination (6). The study shows that chronic stress can increase the progression of human pre-B cell acute lymphoblastic leukaemia in an orthotopic mouse model through an indirect pathway that is regulated by $\beta$-adrenergic signalling (10). Beta-blockers suppress beta receptors and diminish the activity of beta agonists. Epidemiologic studies have associated the use of Beta-blockers with declined rates of progression for various solid tumours, and preclinical pharmacologic and biomarker studies are now laying the foundation for translation of $\beta$-blockade as a new adjuvant offered as an alternative to the existing therapeutic strategies in clinical oncology (6).

Numerous retrospective case control studies suggest that the use of Beta-blockers before the diagnosis of cancer could have a preventive and protective effects on non-small cell lung carcinoma, melanoma, and breast, pancreatic and prostate cancers (11).

In our study, propranolol caused apoptosis by enhancing the activity of caspase-3, and the expression of bax, wee 1, gadd153, grp78 and AIF reduced bcl-2 which is an antiapoptotic protein. Propranolol also diminished the viability of human cSCC cells. It was showed that beta-adrenergic receptors had a higher frequency of expression in oral squamous-cell carcinomas compared with normal cells, and the expression of beta-adrenergic receptors was associated with cervical lymph node metastasis, age, tumour size, and clinical stage (12). A study has demonstrated that propranolol also decreased Ki67, suppressed the phosphorylation of AKT, BRAF, MEK1/2 and ERK1/2, and stimulated the G0/G1/S phase arrest. These studies indicate that propranolol hinders melanoma by stimulating the intrinsic apoptosis pathway and blocking the MAPK and AKT pathways (3). Other studies have examined also the mechanisms of anti-tumour activity of Beta-blockers. Lin X et al revealed that the non-selective $\beta$-adrenergic receptor ( $\beta$-AR) agonist, isoproterenol. remarkably enhanced the activation of ERK/MAPK signalling pathway in pancreatic cancer cells (13). Huang's research demonstrated that norepinephrine activates pancreatic cancer cell proliferation, migration and invasion through 
801-804

$\beta$-AR-dependent activation of the P38/MAPK pathway (14). Other studies showed that propranolol and other Beta-blockers decreased pancreatic cancer and MAPK activity $(15,16)$. The suppression of MAPK is an extensively used mechanism for the purpose of treating melanoma (17). Apoptotic pathways are crucial to cancer development and chemotherapeutic resistance (18).

The combination of propranolol and dichloroacetate increases the effects of chemoradiation and sensitizes the resistant head and neck SCC cells to cisplatin and radiation. This new therapeutic combination offers a promising treatment method which may surmount some of the limitations of targeting individual metabolic pathways in cancer (19).

Clinical results show that propranolol diminished the head and neck SCC viability, induced apoptosis, and inhibited production of the proangiogenic protein VEGF (20). The data implicate $\beta 2 \mathrm{AR}$ as a modulator of mitochondrial metabolism and disease progression in human papilloma virus $(+)$ head and neck SCC, and call for further research into the use of Beta-blockers as low-cost, relatively tolerable, complementary treatment options in the clinical management of this disease (21). A proof-of-principle study revealed that beta-blocker therapy remarkably reduces distant metastases, cancer recurrence, and cancer-specific mortality in breast cancer patients offering a novel function for beta-blocker therapy (22).

\section{Conclusion}

In conclusion, our study demonstrated that propranolol suppressed human basal cell carcinoma cells by stimulating the apoptotic mediators. It also revealed the necessity for an extensive epidemiological study leading to randomised clinical trials for beta-blocker adjuvant therapy in cSCC treatment.

\section{References}

1. Yanagi T, Kitamura S, Hata H. Novel therapeutic targets in cutaneous squamous cell carcinoma. Front Oncol 2018; 8: 79.

2. Hale EK, Hanke CW. Squamous cell carcinoma. https://www.skincancer.org/skin-cancer-information/squamous-cell-carcinoma.

3. Zhou C, Chen X, Zeng W et al. Propranolol induced G0/G1/S phase arrest and apoptosis in melanoma cells via AKT/MAPK pathway. Oncotarget 2016; 7(42): 68314-68327.

4. Fernandez-Pineda I, Williams R, Ortega-Laureano L, Jones R. Cardiovascular drugs in the treatment of infantile hemangioma. World J Cardiol 2016; 8 (1): 74-80.

5. Entschladen F, Drell TL, Lang K, Joseph J, Zaenker KS. Tumourcell migration, invasion, and metastasis: navigation by neurotransmitters. Lancet Oncol 2004; 5 (4): 254-258.
6. Chakroborty D, Sarkar C, Basu B, Dasgupta PS, Basu S. Catecholamines regulate tumor angiogenesis. Cancer Res 2009; 69(9): 3727-3730.

7. Cole SW, Sood AK. Molecular Pathways: Beta-Adrenergic Signaling in Cancer. Clin Cancer Res 2012; 18 (5): 1201-1206.

8. Que SKT, Zwald FO, Schmults CD. Cutaneous Squamous cell carcinoma: Incidence, risk factors, diagnosis, and staging. J Am Acad Dermatol 2018; 78 (2): 237-247.

9. Que SKT, Zwald FO, Schmults CD. Cutaneous squamous cell carcinoma: Management of advanced and high-stage tumors. J Am Acad Dermatol 2018; 78 (2): 249-261.

10. Lamkin DM, Sloan EK, Patel AJ et al. Chronic stress enhances progression of acute lymphoblastic leukemia via $\beta$-adrenergic signaling. Brain Behav Immun 2012; 26 (4): 635-641.

11. Akbar S, Alsharidah MS. Are beta blockers new potential anticancer agents? Asian Pac J Cancer Prev 2014; 15 (22): 9567-9574.

12. Shang ZJ, Liu K, Liang DF. Expression of beta2-adrenergic receptor in oral squamous cell carcinoma. J Oral Pathol Med 2009; 38 (4): 371-376.

13. Lin X, Luo K, Lv Z, Huang J. Beta-adrenoceptor action on pancreatic cancer cell proliferation and tumor growth in mice. Hepatogastroenterology 2012; 59 (114): 584-588.

14. Huang XY, Wang HC, Yuan Z, Huang J, Zheng Q. Norepinephrine stimulates pancreatic cancer cell proliferation, migration and invasion via $\beta$-adrenergic receptor-dependent activation of P38/MAPK pathway. Hepatogastroenterology 2012; 59 (115): 889-893.

15. Zhang D, Ma QY, Wang Z et al. $\beta 2$-adrenoceptor blockage induces $\mathrm{G}(1) / \mathrm{S}$ phase arrest and apoptosis in pancreatic cancer cells via Ras/Akt/ NFKB pathway. Mol Cancer 2011; 10: 146.

16. Munabi NCO, England RW, Edwards AK et al. Propranolol targets hemangioma stem cells via cAMP and mitogen-activated protein kinase regulation. Stem Cells Transl Med 2016; 5 (1): 45-55.

17. Burotto M, Chiou VL, Lee JM, Kohn EC. The MAPK pathway across different malignancies: A new perspective. Cancer 2014; 120 (22): 3446-3456.

18. Zhao YX, Sun ZF. Molecular mechanisms of chemoresistance in head and neck squamous cell carcinoma. Lin Chung Er Bi Yan Hou Tou Jing Wai Ke Za Zhi 2017; 31 (11): 888-891.

19. Lucido CT, Miskimins WK, Vermeer PD. Propranolol promotes glucose dependence and synergizes with dichloroacetate for anti-cancer activity in HNSCC. Cancers (Basel) 2018; 10 (12): pii; E476.

20. Wolter NE, Wolter JK, Enepekides DJ, Irwin MS. Propranolol as a novel adjunctive treatment for head and neck squamous cell carcinoma. J Otolaryngol Head Neck Surg 2012; 41 (5): 334-344.

21. Lucido CT, Callejas-Valera JL, Colbert PL, et al. $\beta 2$-Adrenergic receptor modulates mitochondrial metabolism and disease progression in recurrent/metastatic HPV(+) HNSCC. Oncogenesis 2018; 7 (10): 81.

22. Powe DG, Voss MJ, Zänker KS, et al. Beta-blocker drug therapy reduces secondary cancer formation in breast cancer and improves cancer specific survival. Oncotarget 2010; 1 (7): 628-638. 